\title{
Assessment of Vocational Guidance: The Berufsbilder Test
}

\author{
Lucy Leal Melo-Silva, Sonia Regina Pasian, Renata de Fátima Assoni \\ and Talma Alzira Bonfim (In Memoriam) \\ Universidade de São Paulo, Brazil
}

\begin{abstract}
The object of this study is to assess informative possibilities of some technical indicators of the Test of Photos of Professions (BBT - Berufsbilder test), a projective method to clarify professional inclination, proposed by Martin Achtnich. This psychological evaluation technique is composed of 96 photos of professionals, performing various types of activities. The test subject classifies the photos into three groups: positive (agreeable), negative (disagreeable) and indifferent (neutral). Among those chosen positively, five preferences are chosen and a story is developed that includes them, an activity that is requested two times during the Vocational Guidance process: in the beginning (or middle) and at the end of the intervention. In this study, 160 stories were created by 80 youths, between 15 and 20 years of age, in public and private schools in a mid-sized Brazilian city. The stories were compared in three analytical categories: protagonist, professional conflict and resolution. The results were submitted to Wilcoxon nonparametric statistical analysis ( $p$ $<.05$ ), significant and relevant indicators of resolution being found in the process of occupational choice. This technical resource was shown, from this empirical evidence, to be promising for use in evaluation of intervention processes of Vocational Guidance. Keywords: BBT, Berufsbilder test, vocational guidance, projective test
\end{abstract}

\begin{abstract}
El objetivo de este estudio es evaluar las posibilidades informativas de algunos indicadores técnicos del Test de Fotos de Profesiones (BBT - Berufsbilder test), un método proyectivo para clarificar la inclinación profesional, propuesto por Martin Achtnich. Esta técnica de evaluación psicológica se compone de 96 fotografías de profesionales, realizando varios tipos de actividades. El sujeto del test clasifica las fotos en tres grupos: positivas (agradables), negativas (desagradables) e indiferentes (neutrales). Entre las fotos clasificadas positivamente, se eligen tres preferencias y se desarrolla una historieta que las incluya, actividad que es llevada a cabo dos veces durante el proceso de Orientación Vocacional: al principio (o en medio) y al final de la intervención. En este estudio, 80 jóvenes, de edades entre los 15 y los 20 años, procedentes de escuelas públicas y privadas de una ciudad de tamaño intermedio de Brasil, crearon 160 historietas. Se dividieron las historietas en tres categorías analíticas: protagonista, conflicto profesional, y resolución. Los resultados se sometieron al análisis estadístico no paramétrico Wilcoxon $(p<.05)$, ), encontrando indicadores significativos y relevantes de haber llegado a resolución en el proceso de elección profesional. Debido a esta evidencia empírica, este recurso técnico se muestra prometedor para la evaluación de los procesos de intervención de Orientación Vocacional.

Palabras clave: BBT, Berufsbilder test, orientación vocacional, test proyectivo
\end{abstract}

Correspondence concerning this article should be addressed either to Lucy Leal Melo-Silva or to Sonia Regina Pasian, Av. Bandeirantes, 3900 - Monte Alegre, Ribeirão Preto, SP - BRAZIL - CEP: 14.040-901. Phone: (55 16) 3602-3789 or 3602-3785. Fax: (+55 16) 36024835. E-mail: lucileal@ffclrp.usp.br or srpasian@ffclrp.usp.br 
Upon evaluating the educational methods used in France and intended to guide adolescents, Guichard (1992) noted that professional interventions are no longer limited to the school-work transition, as in the first half of the century. Vocational Guidance is currently viewed as an educational action that prepares adolescents and adults for various choices that they will make in life. New career development concepts arose. "The first was the change in focus at a certain point in time for career development of the course of life. And the second was a personalized concept of career (the human career) related to life roles, scenarios and events" (Guichard, 1992, p. 73). It is the question of the Super theory "of space and the course of life," represented by an image of the rainbow (life-career rainbow), a scheme that aims to integrate the development of the individual throughout life and the articulation of his various social roles (Guichard \& Huteau, 2001).

To make "choices," with a greater or lesser degree of freedom, to define life projects, to plan, to develop a career, to exercise roles, undoubtedly requires reflection on the development of the vocational and occupational identity. For Bohoslavsky (1991), the occupational or professional identity refers to what is done, how it is done, and in what context. The vocational identity, then, consists of the answer to the "why" and the "because" of the professional identity. The occupational refers to the "doing" that allows implementation of a sense of direction in the life of each person. "The vocational without the occupational is fantasy, dreams, hope. The occupational without the vocational is automatization, to do without reason, alienation" (Veinsten, 1994, p. 43).

The process of developing personal and vocational identitity often requires monitoring by a specialized professional, able to discriminate the various components of the process of choosing a profession, above all, within a sociocultural reality such as the current one, where transformations in the world of work are continuous and rapid. For Müller (2001), to carry out an effective Vocational Guidance process within this reality demands specialized training, an appropriate theoretical framework, and additional technical instruments, beyond continuous reflection on the emerging signals in each session. Without this, time may go by without appropriately reaching the intended goals, or rather, without adequate stimulus to assume a professional/occupational option within the individual's socio-cultural context.

In this line, Müller (2001) carried out a long and thorough elaboration on the conditions necessary to optimize Vocational Guidance processes, working within an operative clinical concept. Within the variety of concepts she addresses, she emphasizes the potential assistance of various psychodramatic, Gestaltic, computer, informative, projective, and psychometric techniques, among others. In her words:

The auxiliary techniques are incorporated in a clinical setting as instruments to deepen the subjects' knowledge of themselves, of others, of the task and of the occupational reality, bringing a variety of data that allow us to acquire further qualified information about the consultants, as well as to monitor and promote changes in them, in less time (Müller, 2001, p. 30).

In the current competitive reality of the work world, the degree of efficacy of Vocational Guidance may be a decisive factor in the possibilities of success or professional frustration. The literature in the area has increasingly indicated the need to seek diverse development strategies for this guidance process, with significant theoretical advances. One of the intended goals in these theoretical-technical reflections on Vocational Guidance is the evaluation of the process itself, in the attempt to optimize its therapeutic scope.

How to evaluate the methods of intervention in Vocational Guidance is a complex question, considering: (a) the range of determining factors in career choice, (b) the definitions of the concepts in this broad area of knowledge, (c) the conceptual changes in the strategies embedded in programs and services in this area, (d) the goals of the intervention strategies, (e) the methods of intervention, (f) the differences in psychological, pedagogical or socioeconomic approaches, $(\mathrm{g})$ the strategies for assessment of the processes and results, and (h) the rapid changes in manwork relations, among other issues.

Upon completing studies on the assessment of the efficacy of career counseling in Canada, Flynn (1994) noted that the literature was sparse. The findings show career counseling as effective and comparable to the efficacy achieved in psychological, educational and behavioral interventions. However, "It is necessary to continue to expand and deepen our knowledge of the reasoning behind why career counseling is effective, with whom, under what conditions, and with what results" (Flynn, 1994, p. 272). For the author, little emphasis was given to issues of the counseling process. Hiebert (1994) also emphasized the importance of evaluation of the interventions developed in Vocational Guidance, considering processes and results as interlaced in the counseling itself.

What is the impact of counseling programs and services in the life of youths and adults? A large number of approaches, models, and strategies exist in relation to career development (French et al., 1994). According to these authors, career development expanded well beyond the first action models that focused on combining personal attributes with professional characteristics. The expansion occurred with the intention of assisting the clients to plan and develop their careers, understanding that decisions are made throughout life (Melo-Silva \& Jacquemin, 2001).

Guichard (1992) analyzed some research on assessment of the methods employed in Vocational Guidance in France, and raised various relevant issues about the methodological bases of the research that were aimed at comparing the efficacy of the methods used. In relation to the methods, they differ in the conceptual and ideological models, the intermediate goals, exercises, activities, time, and the 
theoretical link between the proposed tasks and intended goals. Fouad (1994) made some recommendations for future research in the area. Among them, he emphasized the necessity for more precise information about the career counseling process and the efficacy of the interventions (Melo-Silva \& Jacquemin, 2001).

A diagnosis of the Brazilian situation of guidance and professional information was carried out by Pimenta and Kawashita (1986), pointing out that the goals of the programs are imprecise, diffuse, and poorly operationalized; the clientele is diversified with regard to socio-economical conditions, level of academic achievement, and interests; the contents of the programs are based on fragmented concepts of the human-work relation; various professionals act, but not complementarily, as would be desirable. Traditional models of intervention are adopted, founded on models that value the characteristics of the individuals and professions. The authors make recommendations of a theoretical and technical nature, among which the constant evaluation of information and professional guidance programs is emphasized. It is in this context of the need for evaluation of the processes and results of Vocational Guidance that the present study arises.

In the development of Vocational Guidance processes in Brazil, in a clinical-operative approach, techniques and dynamics that stimulate the participation of the individuals being guided have been used in professional training activities with students in a psychology course from a public state institution of higher learning. It should be clarified that the approach in question is psychological and, above all, without neglecting the cultural, social, and economic factors that influence career choice in the Vocational Guidance process developed and assessed. The concern with instruments (individual and group) for evaluation of the processes and results of the interventions, in this context, is in harmony with the development of some of the minimally required competencies of the advisor, according to Niles (1997) and the Declaration of the Qualification Criteria of the Advisor (which was approved by the Assembly of the International Association for Educational and Vocational Guidance): that is, to evaluate the individuals' interests and to evaluate the guidance methods. In this Assembly, a committee was formed to study a proposal for the definition of the international competencies for educational and vocational counselors. The study, concluded in 2003, created a model of central and specialized competencies. Among the specialized competencies, the first is to complete evaluation, or to proceed to:

....analyze the needs of the individuals or groups for whom the program is intended, and, also the context in which they are used, including all of the persons involved. The goal is to integrate and evaluate data from inventories, tests, interviews, scales and other techniques that measure abilities, aptitudes, barriers, life roles, interests, personality, values, attitudes, educational achievement, and abilities of the individual, as well as other relevant information. This specialization includes related, yet distinct, abilities for the interpretation of tests, or to explain to the client the results of an evaluation and its implications (Repetto Talavera, Liévano, Soto, Ferrer-Sama, \& Hiebert, 2004, p. 5).

As Savickas (2004) noted, vocational evaluation plays a central role in career counseling. For this researcher, a comprehensive career evaluation is that which focuses on the client's problem about making a decision and the tasks of development (evaluation of the problem) and, at the same time, seeks to understand the person with regard to their traits and characteristics, such as aptitudes and interests (evaluation of the person). Leitão (2004) contributes significantly to the debate over psychological evaluation in Academic and Vocational Guidance with a book in Portuguese in which she presents authors who collaborate with reflections on the evaluation of intelligence, learning, aptitudes, values, interests, maturity, vocational exploration, vocational indecisions, motivational processes, and the process of intervention in Vocational Guidance.

In intervention in Vocational Guidance, object of this study, the focus is on evaluation of interests and motivations. One of the resources used for performing the individual diagnosis is the Test of Photos of Professions (BBT): a projective method for clarification of professional inclination (Achtnich, 1991). This method offers to the counselor and to the adolescent a greater knowledge of the needs, interests, motivations, and possible conflicts to be addressed in the psychological intervention.

Achtnich (1991) developed the BBT (Berufsbilder Test) in the 1970s in Switzerland, seeking, by means of photographs of professional activities, a technique to clarify professional inclinations, associated with the projective possibilities of personal needs and motivations. This instrument has proved to be useful, precise, and valid in various socio-cultural contexts (Achtnich, 1988; Boudrenghien, 1983; De Ketele, 1982; Jacquemin, 1989, 2000; Jacquemin et al., 2001, 2002, 2003; Leitão, 1993; Leleux, 1982). The basic information about this projective psychological evaluation technique may be sought in the original publications from the author or in the Brazilian Portuguese translation of his main book (Achtnich, 1991).

The BBT underwent a long standardization process for the Brazilian population for the last two decades, reiterating its informative possibilities on the personal inclinations and the motivational profile of an individual or of professional groups, helping to solve the dilemmas experienced by the individuals who seek Vocational Guidance in this context. The BBT-Br Form proceeded from the long adaptation process of the BBT in Brazil. It was created in both masculine and feminine versions, with broad reformulation of the photos used in the technique, as shown in detail in the works of Jacquemin (2000) and Jacquemin et al. (2003).

The use of the BBT in Brazilian practices has shown favorable results in the Vocational Guidance field (Bernardes, 
2000; Melo-Silva \& Jacquemin, 1995, 1997, 2001; MeloSilva \& Noce, 2004; Melo-Silva, Noce, \& Andrade, 1999; Melo-Silva \& Santos, 1998; Ribeiro, 1998; Sbardelini, 1997). And beyond this application, the BBT has been useful in career retraining, in processes of adaptation to work, and in training and personnel selection, as noted by Welter (1998). Furthermore, it can be applied in psychodiagnostic processes, in general, elucidating the motivational characteristics and interests of adolescents and adults in various socio-cultural contexts.

The BBT contributed to the identification of multiple indicators of the motivations and needs of the people seeking realization through occupation/profession, attempting to find available ways to resolve the internal demands as well as the external possibilities, thus favoring the mental health of the individual. Within this technical richness, the composition of a story with the five preferred photos from the BBT has been shown to be a relevant indicator in prognostic terms, as revealed in studies of Melo-Silva and Jacquemin (1995, 1997, 2000), Melo-Silva and Santos (1998), and Melo-Silva, Assoni, and Bonfim (2001).

Application of the BBT consists of classifying the preferences and rejections of the activities represented in 96 photos of professions, creating projective associations about the photos of interest, and making up a story about the five preferred photos. Upon completion of the Vocational Guidance process (in later sessions), a complimentary task of re-creating the story about the five preferred photos from the BBT is requested. However, in this step, individuals are asked to visualize themselves in the future, creating their final story as though ten years of their life had gone by. This possibility of projective reflection about the future has been shown to be very enriching in the evaluation of the degree of vocational maturity and the process of formation of a professional identity in the individual, reiterating the possibilities of technical contribution of the BBT in the Vocational Guidance processes. The content of these stories (created twice during the guidance process) provides indicators to comprehend the vocational conflict and the possibilities for its resolution. For this reason, this technique was chosen as the focus of this present work, in an attempt to analyze the results of a Vocational Guidance intervention in Brazilian reality.

The content individually projected by the adolescents in these stories has been analyzed based on the following evaluative categories: protagonist, professional conflict, outcome, temporality, and title of the story. These variables have proven empirically adequate to identify the degree of conflict resolution of the adolescents' occupational choices, according to studies of Melo-Silva and Jacquemin (1997), Melo-Silva and Santos (1998), Melo-Silva, Assoni, and Bonfim (2001).

Within this context, the present work aims to reveal the informative possibilities of the BBT (Achtnich, 1991) to evaluate the degree of resolution and efficacy in Vocational Guidance processes, within a clinical-operative concept. It will focus on the analysis of only part of the data from the $\mathrm{BBT}$, that is, the stories from the five preferred photos, created by the students at the end of the Vocational Guidance process. The comparison of these stories at two moments of the evaluation process has suggested internal modifications in the self-concept of these adolescents concerning their professional options and possibilities of success in their life projects. Thus, the preventive character of the Vocational Guidance is reiterated, optimized by the resource of the projective technique of the BBT.

\section{Method}

\section{Participants}

The participants in this study included 80 adolescents, 23 male and 57 female, between 15 and 20 years of age, recruited from the Professional Guidance Service of the Center of Research and Applied Psychology of the Ribeirão Preto Faculty of Philosophy, Sciences and Letters of the University of São Paulo. These adolescents spontaneously sought out the service, referring to difficulties in their professional decision process, seeking assistance in this sense. They were students from public and private high schools in Ribeirão Preto (SP), Brazil. They were attended to in Vocational Guidance for 8 to 12 group sessions.

All of the participants were duly informed of the goals of this intervention/research and consented to the present publication, signing a consent form for the use of their data, provided their identity remained confidential. For those under 18 years of age, the parents or guardians signed the respective authorization for the intervention and research.

\section{Instruments and Procedure}

Based on a perspective of development of the vocational and professional identity, analysis of the Professional Guidance Service of Center of Research and Applied Psychology was the focus of this study. This service serves individuals who spontaneously seek Vocational Guidance, to assist them in the elaboration of their life projects.

Vocational Guidance is performed in groups or individually in this service. Didactically, the process is developed around four thematic axes: choice, self-knowledge, information about professions, and access to the university and to the working world. The process is meant to provide a space for the adolescents to reflect on the aspects that influence career choice (i.e., interests, individual values, family, society, professional stereotypes, and changes in the working world), in order to facilitate decision making based on conscious and responsible choices.

To serve these adolescents in Vocational Guidance, the minimal material conditions inherent in the process were used. In other words, an appropriate place for individual 
and/or group sessions, informative materials about professions, the transformations in the world of work, and, as the focus of this study, Achtnich's (1991) BBT, in the masculine (Achtnich, 1971) and feminine (Achtnich, 1973) versions. Within the diversity of responses obtained with this projective technique, the stories created by the adolescents about their five preferred BBT photos were examined in this work.

The 80 adolescents were individually evaluated with the BBT, following its standardized technique (Achtnich, 1991). They were asked to create their stories in the middle of the Vocational Guidance process. At the end of the process, they were asked to re-create a story about their five preferred photos chosen from among the 96 photos in the BBT, except this time, visualizing themselves 10 years in the future.

The focus of this study was the analyzed material, that is, the 160 stories created by the adolescents, who were evaluated twice during the Vocational Guidance process, comparing the technical indicators of these projective productions. The content of the stories was classified by psychologists with clinical experience with the BBT into the following categories: protagonist, professional conflict, and outcome. A comparative analysis of these indexes at the two times of the evaluation process, for all of the 80 adolescents, was subsequently carried out.

These categories and their analytical sub-categories of the adolescents' productions were analyzed a priori qualitatively: the stories were read several times with the intention of comprehending their life's projects. Subsequently, the results, in terms of the frequency of the categories of analysis, were compared with the nonparametrical statistical procedure (Wilcoxon's test, using $p \leq 0.05$ ), to identify significant differences between the middle and the end of the Vocational Guidance process. We sought to identify variables that indicated modifications in the personal position of the adolescents, faced with their occupational/professional dilemmas, which could be related to the clinical and operative intervention, showing whether or not the intervention was technically efficacious.
Results

In order to organize the indexes of the adolescents' position before making their professional/occupational choices, their results in each category and evaluative subcategory from the 160 stories created about their five preferred BBT photos were systematized as shown in Tables 1,2 , and 3 .

Table 1 shows the classification of the protagonists of the narratives, from the analysis of the use of personal pronoun by the adolescent as frequently in the first as in the second story from the BBT. In the first narrative, 28 adolescents wrote a story with the protagonist in the firstperson singular, whereas, in the second story, 41 stories contained protagonists in the first-person singular.

Statistical analysis of this data showed a significant difference between the stories created by the adolescents at these two times in the Vocational Guidance process ( $p=$ .004). There was a significant increase in the use of the firstperson singular pronoun in the stories created by the adolescents in the final intervention technique, indicating the possibility of the emergence of a professional role, enhanced by the intervention in Vocational Guidance, as the adolescents considered themselves to be the protagonists of the story. An example of this situation may be seen in the following excerpt: "I think of my future life as being rushed, happy, and based on personal contacts" (female, 17 years, college preparatory course).

We also observed that the protagonist was presented in the third-person singular in 37 narratives in the first story, whereas, in the second story, this number decreased to 24 , showing a statistically significant difference $(p=.009)$. This decrease of the use of the more impersonal form of the story (the thirdperson singular: he or she) may also indicate a more effective professional identification, because the form was replaced, mainly by the first-person singular. The frequency of occurrence of protagonists in the stories in the other evaluative subcategories ("various pronouns," "other pronouns") revealed no statistically significant changes in the two evaluative moments currently addressed. This data confirm the preliminary data obtained by Melo-Silva and Jacquemin (1997).

Table 1

Distribution (Simple Frequency) of Protagonists Identified in the Adolescents' Stories $(n=80)$ about their five Preferred BBT Photographs During and at the End of the Vocational Guidance Process

\begin{tabular}{lccc}
\hline & \multicolumn{3}{c}{ Stories } \\
\cline { 2 - 4 } Protagonist & First $N$ & Second $N$ & Statistical Comparison \\
\hline $1^{\text {st }}$ Person Singular & 28 & 41 & $.004 *$ \\
$3^{\text {rd }}$ Person Singular & 37 & 24 & $.009 *$ \\
Various Pronouns & 07 & 11 & .164 \\
Other Pronouns & 08 & 04 & .426 \\
\hline
\end{tabular}

* Wilcoxon's test, significant at $p \leq .05$. 
Further to the analysis of the production of the narratives by the adolescents about their preferred BBT photos, Table 2 shows the number of careers present in the professional conflict described in the stories at the two moments of the Vocational Guidance process.

Analysis of this table shows that, in the first story, 54 adolescents displayed a professional conflict between various professions, which may indicate that they found themselves in a dilemma, according to Bohoslavsky (1991). An example of this situation may be seen in the following explanation:

Once I went with my mom to the hospital and was fascinated by the work of the nurse who was there. Leaving this room, I went with my brother to Pediatrics and he liked the doctor a lot, because he did this with love and dedication... On this same day, at school, I had a chemistry and biology lab, and I started to see how that was enjoyable and how I identified with all of that..." (female, 16 years, $3^{\text {rd }}$ year of high school).

According to Melo-Silva, Assoni, and Bonfim (2001), to create stories with various careers indicates professional conflict, showing difficulty in choosing and elaborating losses, which reveals that the individual is not ready to make a decision. At the same time, it may indicate broad horizons in the world of work, an element expected at the beginning of the intervention process, unlike that which occurs at the end of the Vocational Guidance process, where greater specificity of firm choices is expected.
In this study, in the second story created by the adolescents, the number of stories with various professions decreased to 32 , indicating personal maturation regarding occupation choice. Comparing this data with the initial frequency, this index is statistically different $(p=.000)$ at the two times of the Vocational Guidance process. This may indicate that this intervention was designed to create significant space for reflection and maturation of ideas regarding the choice of a career for the adolescents being assessed.

Another statistically significant difference is the professional conflict category: the number of stories that presented a profession increased from the first to the second story ( $n=6$ vs. $n=23$, respectively). This indicator suggests the possibility of resolution of professional conflict with a possible decision, enhanced by the intervention process. The following excerpt may be an example of this process: "I am trained in veterinary medicine, have a calm life, and am very successful in my career" (female, 16 years, $2^{\text {nd }}$ year of high school). In the other subcategories that evaluate the conflicts identified in the stories ("two professions," and "nonspecific careers"), the differences between the two assessment moments (first and second stories) were statistically nonsignificant.

Table 3 presents the types of outcome identified in the two narratives created by the adolescents about from their five preferred BBT photos.

Table 2

Distribution (Simple Frequency) of Professional Conflicts Identified in the Adolescents' Stories $(n=80)$ about their five Preferred BBT Photographs During and at the End of the Vocational Guidance Process

\begin{tabular}{lccc}
\hline & \multicolumn{2}{c}{ Stories } & \\
\cline { 2 - 3 } Conflict & First & Second & Statistical Comparison \\
\hline Two Professions & 10 & 09 & .847 \\
Various Professions & 54 & 32 & $.000^{*}$ \\
Non-specific Careers & 11 & 16 & .277 \\
One Profession & 06 & 23 & $.002^{*}$ \\
\hline
\end{tabular}

* Wilcoxon's test, significant at $p \leq .05$.

Table 3

Distribution (Simple Frequency) of Outcomes Identified in the Adolescents' Stories $(n=80)$ about their five Preferred BBT Photographs During and at the End of the Vocational Guidance Process

\begin{tabular}{lccc}
\hline & \multicolumn{2}{c}{ Stories } & \\
\cline { 2 - 3 } Outcome & First & Second & Statistical Comparison \\
\hline Personal and/or Professional Achievement & 19 & 36 & $.000^{*}$ \\
Possibility of Resolution & 12 & 15 & .548 \\
In Professional Conflict & 41 & 26 & $.010^{*}$ \\
Tragic Ending & 08 & 03 & .063 \\
\hline
\end{tabular}

* Wilcoxon's test, significant at $p \leq .05$. 
Analyzing the data from this table, it is noted that, in the first narrative, 19 stories presented an outcome with professional and/or personal accomplishment. This number increased significantly $(p=.000)$ in the second story $(n=$ 36 ), indicating elaboration of the conflict with a subsequent decision. Examples of this situation may be seen in the following scenarios:

I am an important guy who makes predictions about the weather... I struggled a lot to achieve my goal, and today I am married to a very pretty woman and have two children that are very bright and play soccer very well. I am happy to be working in this area (male, 17 years, $3^{\text {rd }}$ year of high school).

I, Martha, ten years from now, will be 27 years old: I intend to be working in a laboratory doing a lot of research... I want to have three children. They will all go to the psychologist for guidance in their professional choice. This helped me a lot. (female, 17 years, $3^{\text {rd }}$ year of high school).

In the first narrative, most of the adolescents $(n=41)$ ended their stories with the present professional conflict, thus showing some difficulty to find a satisfactory resolution as far as a career choice is concerned. In the second story, a significant decrease was observed in the stories that presented professional conflict $(n=26, p=.010)$, indicating elaboration and the possibility of resolution of the conflict by the adolescents studied.

The statistically significant differences found in these two subcategories that evaluate the story outcome (decrease in the number of outcomes that present professional conflict and increase in the number of outcomes with personal and/or professional accomplishment) empirically confirm the hypothesis that the Vocational Guidance process with the BBT enhances elaboration and decision making.

Despite the nonsignificant differences between the two moments in the Vocational Guidance process, the other subcategories ("tragic ending" and "possibility of resolution") of the outcomes of these stories displayed qualitatively relevant aspects. Thus, there was a decrease in the number of tragic endings from the first story to the second ( $n=8$ vs. $n=3$, respectively), indicating elaboration and integration of the morbid and aggressive content projected by the adolescents about their anxieties in relation to professional/occupation choice.

\section{Discussion and Conclusions}

The present study showed the possibility of application of the BBT of Achtnich (1991) as an auxiliary instrument in the analysis of the efficacy of Vocational Guidance processes with adolescents in Brazilian high schools. Despite the fact that qualitative analysis has received little emphasis in the literature, there is growing concern about evaluation methods that include qualitative analysis interlaced with quantitative analysis and that seek solutions for the limits of both methods of analysis, as noted by Fouad (1994) and
McMahon and Patton (2002). In this sense, this study aimed to contribute some reflections on the process of occupational choice, based on stories created by clients from the stimuli provided by the projective technique of clarification of professional inclination - BBT.

Counselors have increased the use of qualitative analysis in guidance procedures in the post-modern era and there have been movements from objectivity to subjectivity or from scores to career stories, as indicated by Savickas (2004) and McMahon and Patton (2002). For these authors, qualitative analysis encourages subjects to tell their stories and to discover the subjectivity of their careers. The use of the BBT through the complementary procedure (telling stories at two different times during the Vocational Guidance process) allowed the expression of the subjectivity of the careers in a life-project perspective.

The stories allow the content analysis as a function of evaluative categories that permit subsequent statistical treatment, rating the frequency of their occurrence in the adolescents' creations. As McMahon and Patton (2002) point out, the stories were analyzed to emphasize the importance of subjectivity in career counseling processes. Thus, the client is active, and the counselor is just a facilitator of the process of becoming aware.

Examining the technical indicators of the stories created (from the five preferred BBT photos) during and at the end of the guidance process, it was possible to identify changes in the adolescents' stories at these two moments of the intervention. In the second story, most of the students experienced their role as the protagonist of their stories, decreasing the number of desired professions and imagining an outcome with personal and professional accomplishment. Thus, the technical indicators of maturity in assuming of a vocational/professional identify were revealed (Melo-Silva \& Jacquemin, 1997).

To be the protagonist of the story shows that one has reached the goals of clarification of professional interests and the possibility of developing a career throughout life, as emphasized by developmental theories (Crites, 1974). Guichard (1992) also underlined this indicator as a sign of conceptual changes in career counseling.

The reasons for the efficacy of Vocational Guidance are permanent questions in the works of Hiebert (1994), Fouad (1994), and Flynn (1994). From this perspective, the current empirical evidence suggests that the results of the Vocational Guidance process herein evaluated is effective, according to the intervention method adopted. From the data obtained, it is inferred that focusing on the clarification of clients' interests, stimulating them to construct a life project and to assume the role of protagonist of their story tends to favor their growth and the process of making individual occupational decisions, which is the focus of the proposed intervention process.

It is emphasized that, during the elaboration of the second story from the BBT, when inviting the adolescents to talk about themselves from a prognostic perspective (imagining themselves ten years later), strong elements of their 
idealization of the future may have been projected, disregarding the real conditions of access to the working world, above all, because of their age-appropriate dreams and fantasies. However, the changes reflected in their stories about the protagonists, professional conflicts, and their respective outcomes may be considered resources, at least initially, for the resolution of vocational/professional dilemmas that lead to the establishment of short-, mid-, and long-term goals. Thus, hypothetically and anticipating the future, the youth begins the construction of a social work project. In this sense, their professional and vocational identity is constructed, according to Bohoslavsky (1991), Veinsten (1994), and Müller (2001). Upon experiencing being an adult and deciding what to do professionally, the facilitation of the development of a personal and professional identity was observed, even if at the level of narratives and creation of stories, not yet lived. "Participation in an occupational activity is a precious opportunity for the construction of the self" (Guichard, 1992, p. 76). Vocational Guidance makes it possible to help people who have difficulties in self-reflection, and, in this sense, the BBT made self-reflection and updating of the self-concept possible. Much more than a test, this instrument, especially the stories from the five preferred photos, offers learning experiences to the youths (as choosing a career is considered a learning situation), bearing an experiential, cognitive, and developmental dimension (Pelletier, Noiseux, \& Bujold, 1982).

With the informative possibilities of the present work, the clinical and empirical utility of the BBT (Achtnich, 1991) as a projective instrument to clarify motivational inclinations and as a technical aid in the evaluation of the processes and results of clinical-operative intervention in Vocational Guidance is evident. Future research could extend the possibilities of the use of this projective technique through longitudinal studies and its comparison with other instruments, methods, and psychological evaluation techniques. Moreover, research in other socio-cultural contexts is encouraged, as this would enrich the resources in this area of practical professional psychology.

\section{References}

Achtnich, M. (1971). Berufsbilder-Test: Männliche Bilder. Bern: Verlag Hans Huber.

Achtnich, M. (1973). Berufsbilder-Test:Weibliche Bilder. Bern: Verlag Hans Huber.

Achtnich, M. (1988). Introduction au Test de Photos de Professions (BBT) et a son utilisation dans la consultation d'orientation professionnelle et de carriere. Revue de Psychologie Appliquée, 38, 295-324.

Achtnich, M. (1991). O BBT - teste de fotos de profissões: Método projetivo para a clarificação da inclinação profissional (J. Ferreira Filho, Trans.). São Paulo: Centro Editor de Testes e Pesquisas em Psicologia.
Bernardes, E.M. (2000). O teste de fotos de profissões (BBT) de Achtnich: Um estudo longitudinal com adolescentes. Unpublished master's thesis, Faculdade de Filosofia, Ciências e Letras de Ribeirão Preto, Universidade de São Paulo, Ribeirão Preto.

Bohoslavsky, R. (1991). Orientação Vocacional: A estratégia clínica (J. M. V. Bogart, Trans.). São Paulo: Martins Fontes.

Boudrenghien, G. (1983). Contribution a l'utilisation du Berufsbilder-Test de M. Achtnich. Bulletin de Psychologie Scolaire et d'Orientation, 32, 49-61.

Crites, J. O. (1974). Psicologia Vocacional. (N. Dottori \& S. Vetrano, Trans.). Buenos Aires: Editorial Paidós.

De Ketele, R. (1982). Le Berufsbilder-Test (BBT) de Martin Achtnich dans la consultation d'orientation: Instrument de mesure ou support d'une demarche? Bulletin de Psychologie Scolaire et d'Orientation, 31, 14-25.

Flynn, R.J. (1994). Evaluating the effectiveness of career counselling: Recent evidence and recommended strategies. Special Issue: Issues and solutions for evaluating career development programs and services. Canadian Journal of Counselling, 28, 270-80.

Fouad, N.A. (1994). Annual review 1991-1993: Vocational choice, decision making, assessment and intervention. Journal of Vocational Behavior, 45, 25-76.

French, F., Hiebert, B., \& Bezanzon, L. (1994). Introduction and emerging evaluation model for changing times. Canadian Journal of Counselling / Revue Canadienne de Counseling, 28, 261-269.

Guichard, J. (1992). Comparative evaluation of several educational methods used in France for the orientation of adolescents: Tools, results, and methodological problems. European Journal of Psychology of Education, 7, 73-90.

Guichard, J., \& Huteau, M. (2001). Psicologia da Orientação. (A. P. Silva, Trans.). Lisbon: Instituto Piaget.

Hiebert, B. (1994). A framework for quality control, accountability and evaluation: Being clear about the legitimate outcomes of career counselling. Special Issue: Issues and solutions for evaluating career development programs and services. Canadian Journal of Counselling, 28, 334-345.

Jacquemin, A. (1989). L'etat des recherches sur le BBT au Brésil. Bulletin de Psychologie Scolaire e d'Orientation, 41, 95-99.

Jacquemin, A. (2000). O BBT-Br: Teste de Fotos de Profissões Normas, adaptação brasileira, estudos de caso. São Paulo: Centro Editor de Testes e Pesquisas em Psicologia.

Jacquemin, A., Noce, M.A., Assoni, R.F., Okino, E.T.K., Kawakami, E.A., \& Pasian, S.R. (2001). O Berufsbilder Test (BBT) de Achtnich: Adaptação brasileira da forma feminina. In Livro de Resumos do IV Encontro da Sociedade Brasileira de Rorschach e outras técnicas de avaliação psicológica (p. 130). São Paulo: Casa do Psicólogo.

Jacquemin, A., Pasian, S.R., Assoni, R. F., Okino, E.T.K., Corlatti, C.T., Kawakami, E.A., et al. (2002). O Berufsbilder-Test (BBT) de Martin Achtnich: Adaptação da Forma Feminina para o contexto cultural brasileiro. (Relatório de pesquisa). Ribeirão Preto: Faculdade de Filosofia, Ciências e Letras de Ribeirão Preto - Universidade de São Paulo. 
Jacquemin, A., Pasian, S.R., Assoni, R.F., Okino, E.T.K., Corlatti, C.T., Kawakami, E.A., Frazatto, L., \& Jardim, M.L.C. (2003). O Berufsbilder-Test (BBT) de Martín Achtnich: Adaptação da forma feminina para o contexto cultural brasileiro (Relatório de pesquisa). Ribeirão Preto: Faculdade de Filosofia, Ciências e Letras de Ribeirão Preto, Universidade de São Paulo.

Leitão, L.O.G.M. (1993). Contributos para um modelo de avaliação dinâmica dos interesses - Ensaio sobre um método projetivo de análise das tendências profissionais - o "Berufisbilder- test". Unpublished doctoral dissertation, Faculdade de Psicologia e Ciências da Educação, Universidade de Coimbra, Coimbra.

Leitão, L.M. (Ed.). (2004). Avaliação psicológica em orientação escolar e profissional. Coimbra: Quarteto.

Leleux, A.L (1982). Berufsbilder-Test (BBT) de Martin Achtnich: Presentation du test. Bulletin de Psychologie Scolaire et d'Orientation, 3, 1-13.

McMahon, M., \& Patton, W. (2002). Using qualitative assessment in career counselling. International Journal for Educational and Vocational Guidance, 2 (1), 51-66.

Melo-Silva, L.L., \& Jacquemin, A. (1995). Contribuição para a interpretação do BBT de Martin Achtnich: A história das cinco fotos preferidas. In Associação Brasileira de Orientação Profissional (Ed.), Anais do II Simpósio Brasileiro de Orientação Vocacional e Profissional (pp. 301-311). São Paulo: ABOP.

Melo-Silva, L.L., \& Jacquemin, A. (1997). L'histoire des cinq photos préférées au BBT à deux momentes du processus d'orientation professionnelle. Revista de Pedagogie, 1, 65-69.

Melo-Silva, L.L., \& Jacquemin, A. (2000). Contribuições para a interpretação do BBT de Martin Achtnich: A história das cinco fotos preferidas. Psic Revista da Vetor, 1, 72-79.

Melo-Silva, L.L., \& Jacquemin, A. (2001). Intervenção em Orientação Vocacional / Profissional: Avaliando resultados e processos. São Paulo: Vetor.

Melo-Silva, L.L., \& Noce, M.A. (2004). O teste de fotos de profissões (BBT) enquanto método projetivo em orientação profissional: estudo de caso. In Z.B. Vasconcelos \& I.D. Oliveira. (Eds.). Orientação Vocacional: Alguns aspectos teóricos, técnicos e práticos. São Paulo: Vetor.

Melo-Silva, L.L., Noce, M.A., \& Andrade, P.P. (1999). A Estrutura de inclinação profissional em adolescentes. In Associação Brasileira de Orientação Profissional (Ed.), Livro de Resumos do IV Simpósio Brasileiro De Orientação Vocacional \& Ocupacional / Encontro de orientadores profissionais do Mercosul (p. 28). Florianópolis: ABOP.
Melo-Silva, L.L., \& Santos, M.A. (1998). O BBT como instrumento diagnóstico em orientação profissional: Uma abordagem psicodinâmica. Revista da ABOP, 2, 59-76.

Melo-Silva, L.L., Assoni, R.F., \& Bonfim, T.A. (2001). A história das cinco fotos preferidas do BBT: Proposta de um modelo de análise. In Associação Brasileira de Orientação Profissional (Ed.), Anais do IV Simpósio Brasileiro de Orientação Vocacional \& Ocupacional (pp. 171-181). São Paulo: Vetor Editora.

Müller, M. (2001). Orientación vocacional: descubrir el camino. ( $3^{\text {rd }}$ ed.). Buenos Aires: Bonum.

Niles, S.G. (1997). Annual review: Practice and research in career counseling and development. The Career Development Quarterly, 46, 115-141.

Pelletier, D., Noiseux, G., \& Bujold, C. (1982). Desenvolvimento vocacional e crescimento pessoal: Enfoque operatório. (E. F. Alves, Trans.). Petrópolis: Vozes.

Pimenta, S.G., \& Kawashita, N. (1986). Orientação Profissional: Um diagnóstico emancipador (2nd ed.). São Paulo: Loyola.

Repetto Talavera, E., Liévano, B.M., Soto, N.M., Ferrer-Sama, P., \& Hiebert, B. (2004). Competências Internacionais para orientadores profissionais. Revista Brasileira de Orientação Profissional, 5, 1-14.

Ribeiro, A.V.G. (1998). Algumas contribuições para o uso dos métodos BBT e R-O em orientação profissional. Unpublished master's thesis, Faculdade de Filosofia, Ciências e Letras de Ribeirão Preto, Universidade de São Paulo, Ribeirão Preto.

Savickas, M.L. (2004). Um modelo para avaliação de carreira. In L.M. Leitão (Ed.), Avaliação psicológica em orientação escolar e profissional. Coimbra: Quarteto.

Sbardelini, E.T.B. (1997). A reopção de curso na Universidade Federal do Paraná. Unpublished doctoral dissertation, Faculdade de Medicina de Ribeirão Preto, Universidade de São Paulo, Ribeirão Preto.

Veinsten, S.B.G. (1994). La elección vocacional-ocupacional: estrategias técnicas. Buenos Aires: Marymar.

Welter, G. (1998). Uma experiência com o BBT - Teste de Fotos de Profissões em recursos humanos de uma indústria automobilística. In Sociedade Brasileira de Rorschach (Ed.), Anais do III Encontro da Sociedade Brasileira de Rorschach e outros métodos projetivos (pp. 180-184). Ribeirão Preto: SBRo.

Received August, 29, 2006

Revision received June, 23. 2007 Accepted November, 9, 2007 